\title{
Purinergic Receptor
}

National Cancer Institute

\section{Source}

National Cancer Institute. Purinergic Receptor. NCI Thesaurus. Code C17077.

A family of cell receptors that bind purines and are involved in lig and-dependent signaling. 